\title{
THEOLOGICAL DIMENSIONS IN MEMITU RITUALS IN CIREBON
}

\section{DIMENSI TEOLOGI DALAM RITUAL MEMITU DI CIREBON}

\author{
B Busro ${ }^{1}$, Ai Yeni Yuliyanti ${ }^{2}$, Abdul Syukur ${ }^{3}$, Rifki Rosyad ${ }^{4}$ \\ 1,2,3,4 Faculty of Ushuluddin UIN Sunan Gunung Djati Bandung \\ Jl. A.H. Nasution No.105, Cipadung, Kec. Cibiru, Bandung \\ e-mail: ${ }^{1}$ busro@uinsgd.ac.id, ${ }^{2}$ almaulidayeni@gmail.com, \\ ${ }^{3}$ abdul_syukur05@yahoo.com, ${ }^{4}$ rifkirosyad@ uinsgd.ac.id
}

DOI: 10.30959/patanjala.v12i2.636

\begin{abstract}
Indonesia is very famous for its rich culture. Cirebon as one of the districts in West Java is also very thick with its culture. This article discusses one of the cultures in Kedungsana Village Cirebon, the phenomenon of ritual slametan Memitu. The purpose of this study is to examine the practice of ritual slametan Memitu carried out by Kedungsana community together with its theological dimensions. The research subjects were the community of Kedungsana Village, Plumbon District, Cirebon Regency. The process of collecting data through direct observation and to get deep information in interviews, we use a purposive sampling technique. The results of the study found that the purpose of carrying out the ritual slametan Memitu was as a manifestation of gratitude for all the favors that had been given from the "Invisible Power" and also the hope of the smooth birth process. Express gratitude and the request is addressed to those considered to have the power to determine the smooth process of birth. In ritual slametan Memitu, there are theological dimensions that can be identified as belief in Invisible Substance and values for living in harmony together among residents of Kedungsana Village community. The theological dimensions in the earth alms ritual have been developed in such a way as to be in line with the development of social reality.
\end{abstract}

Keywords: slametan, theology, Memitu, ritual

\begin{abstract}
Abstrak
Indonesia sangat terkenal dengan kekayan kebudayannya. Cirebon sebagai salah satu kabupaten di Jawa Barat juga sangat kental dengan budayanya. Artikel ini membahas salah satu budaya di Desa Kedungsana Cirebon, yaitu fenomena tradisi ritual slametan Memitu. Tujuan dari penelitian ini adalah untuk meneliti praktek ritual Memitu yang dilakukan oleh masyarakat Kedungsana bersama dengan dimensi-dimensi teologisnya. Subjek penelitian adalah komunitas masyarakat Desa Kedungsana Kecamatan Plumbon Kabupaten Cirebon. Proses pengumpulan data dilakukan dengan observasi langsung, untuk pendalaman dilakukan wawancara dengan teknik purposive sampling. Hasil penelitian ditemukan bahwa tujuan dilaksanakannya ritual slametan Memitu adalah sebagai manifestasi syukur atas segala nikmat yang telah diberikan dari "Kekuatan Tak Terlihat" dan juga pengharapan kelancaran proses kelahiran. Ungkapan rasa syukur dan permohonan tersebut ditujukan kepada yang diyakini memiliki kekuatan untuk menentukan kelancaran proses kelahiran. Dalam ritual slametan Memitu terdapat dimensi-dimensi teologi yang dapat diidentifikasi sebagai kepercayaan terhadap Zat Yang Gaib dan nilai-nilai untuk hidup rukun berdampingan antar-warga masyarakat Kelurahan Kedungsana. Dimensi-dimensi teologis dalam ritual sedekah bumi ini telah dikembangkan sedemikian rupa agar sejalan dengan perkembangan realitas sosial.
\end{abstract}


Kata kunci: slametan, teologi, Memitu, ritual.

\section{A. INTRODUCTION}

Cirebonese, as a part of Javanese sociocultural milieu and history, also develops various slametan rituals. According to Clifford Geertz, slametan is the Javanese version of the most common religious ceremony in the world. It symbolizes the mystical and social unity of those who participate in it. Families, neighbors, coworkers, relatives, local spirits, dead ancestors, and gods that were almost forgotten, all sat together around one table and therefore bound to a certain social group that was obliged to help each other and work together (Geertz, 1981: 13).

Quotation above reveals that slametan not only involves alive people but also dead ancestors. Slametan is a ceremony that exists in various religious ceremonies in Java and has various meanings. It becomes a medium to express meaningful meaning in social life. This slametan ritual is related and presents in all life aspects, from birth to human death (Afif, 2009: 3). One of it is Memitu ritual.

Memitu ritual is a ritual that is carried out when the gestational ages seven months. It is one part of the life cycle tradition or what Geertz calls rites of passage, which are described as arrows, ranging from simple daily events, from births to large events that arranged more complicated, such as circumcision, marriage, and then ending in a silent death ceremony (Geertz, 1981: 13). In addition, Van Gennep states that the growth stages as an individual, -since their birth, then being children and teenagers, becoming adult, married and parent, until the time they die, - humans experience biological changes and social culture changes that can affect their soul and cause mental crisis. To face the new stage of growth, humans need the regeneration of the spirit of social life earlier. Moreover, Van Gennep considers the series of rites and ceremonies throughout the growth stages or the cycle life as individual is the most important. Those are perhaps the oldest series of rites and ceremonies in human society and culture in many transitional rite cultures. For example, many ceremonies during pregnancy, many ceremonies during childhood, first hair-cutting ceremony, first tooth-out ceremony, baby's first delivering ceremony and so on (van Gennep, 2004: 41).

There are similar ceremonies in other areas, but different names. Those are tingkeban in east Java (Newland, 2001; Rifa'i, 2017), mitoni in several regions of central Java (Baihaqi, 2017; Boanergis et al., 2019), nujuhbulanan in West Java (Juwintan, 2017; Nugraha, 2015). Memitu, Tingkeban, Mitoni, and nujuhbulanan are the same ritual. Tingkeban is derived from the word tingkeb means closed. This term is also called mitoni or memitu that derived from the word pitu. Pitu is Javanese language of the word "seven". It is a traditional ritual of salvation for infants age seven months who are still in the womb. The community belive that those rituals have two meanings: the birth will be smooth, and the baby will become a pious child with good character. Those rituals have a variety of processions, ranging from reading the Koran, bathing with flowers, and the other series.

Many research on Memitu ritual have been widely carried out by previous researchers including researching Memitu from a cultural perspective as local wisdom, has the values of religious awareness, psychological health of pregnant women, and can maintain social integrity as a manifestation of the social and cultural identity of the community (Abdullah, 2018; Adriana, 2012; Boanergis et al., 2019; Wariin, 2014). Other studies examine Memitu in the perspective of Islamic law. Memitu rituals when viewed in Islamic law are permissible as long as they do not conflict with Islamic legal norms. Memitu rituals are included in the category of tradition or Urf, which is a law based on customs that develops in a society 
(Ernawati, 2017; Isa et al., 2019; M Ikhfan, 2019). In addition to these perceptions, several studies reveal that Memitu rituals are related to education. There are educational values of children in the womb in the Memitu ritual, namely the introduction of monotheism (oneness of God) to the child in the womb. In addition, the mitoni tradition also provides spirit to maintain the behavior of expectant mothers and prospective fathers since the child is in the womb (Amirudin, 2019; Rois, 2015; Ulya, 2018). Some studies examine Memitu in relation to social change. Memitu rituals are still carried out because they are adapted to the development of culture. Memitu rituals undergo many changes according to community mining (Busro \& Qodim, 2018; Kumalasari, 2017; Suhartiningsih, 2014). From several studies that have been mentioned, no one has explored Memitu rituals from a theological perspective. This research will try to elaborate on the practice of the ritual tradition of birth slametan conducted by Kedungsana community, especially Memitu Ritual together with its theological dimensions.

\section{B. METHOD}

The subject of the research was the community of Kedungsana Village, Plumbon District, Cirebon Regency. The location was chosen because all citizens embraced Islam but Memitu ritual ceremony was still held and it is an old tradition. Besides, people in Kedungsana Village began to change into modern society. The process of collecting data through direct observation and to get deep information in interviews, we use a purposive sampling technique. Purposive sampling is the choice of who is in the best position to provide needed information. They were chosen because the researchers believe that they represent a certain population (Silalahi, 2010). The existence of the subject of this research is to obtain data that was really needed and very important for this research, namely on how the ritual way and its dynamics from the past until now. The informants are the perpetrators of Memitu rituals, village elders, and religious leaders.

\section{FINDINGS AND DISCUSSION 1. Demographic Conditions of Research Locations}

This section explains the location of Memitu ritual. It is important to get the whole description about the place it's ritual. The location of this study is Kedungsana Village which is included in Plumbon District Cirebon Regency. The area consists of rice fields, settlements, industry and others shown in table 1.

Table 1 Land Use in Kedungsana Village

\begin{tabular}{llc}
\hline No & \multicolumn{1}{c}{ Area } & Large \\
\hline 1. & Settlement & 16,1055 ha \\
\hline 2. & Rice fields & 98,245 ha \\
\hline 3. & Garden & 1 ha \\
\hline 4. & Industry & 9,3000 \\
\hline 5. & Grave & $1,7500 \mathrm{ha}$ \\
\hline 6. & Office space & $0,0400 \mathrm{ha}$ \\
\hline TOTAL & 126,4400 \\
\hline
\end{tabular}

Source: Profile Data of Kedungsana Village.

The area of Kedungsana Village is flowing along Kali Soka or Soka river which divides this area into two regions, Sabrang Wetan (east) and Sabrang Kulon (west). Both are connected by a small bridge so the car cannot pass as shown in figure 1. In the east, it consists of one block, Jamar Jati block. Meanwhile, in the west are Nyimas, Sampurna, and desa blocks.

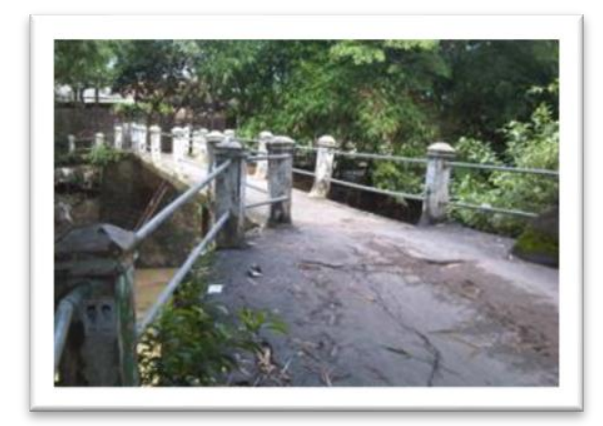

Figure 1 The bridge connecting Sabrang Kulon and Sabrang Wetan

Source: Privat Documentation, 2018 
All populations of Kedungsana Village are Indonesian and Muslim. The population data is shown in table 2 .

Table 2 Population Number of Kedungsana Village

\begin{tabular}{lccc}
\hline \multirow{2}{*}{ Details } & \multicolumn{3}{c}{ Gender } \\
\cline { 2 - 4 } & Male & Female & Number \\
\hline $\begin{array}{l}\text { Population } \\
\text { Number }\end{array}$ & 1997 & 2050 & 4047 \\
\hline $\begin{array}{l}\text { Number of } \\
\text { family } \\
\text { heads }\end{array}$ & 992 & 140 & 1132 \\
& & & \\
\end{tabular}

Source: Population Registration Report of Kedungsana Village in December.

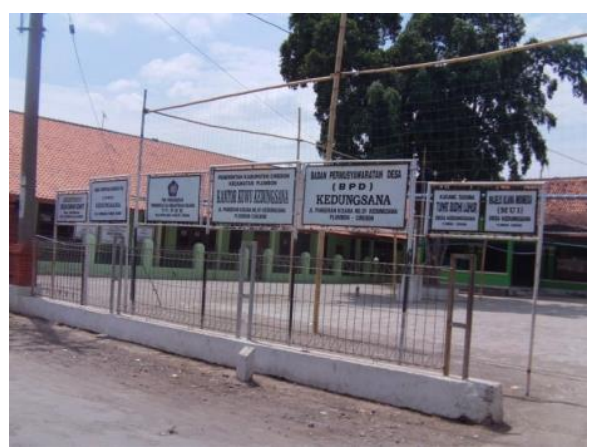

Figure 2 Kedungsana Village Hall Source: Privat Documentation, 2018.

The development of education in Kedungsana Village is proved by the existence of many schools there, either formal or informal schools. There are two state elementary schools, SDN 1 Kedungsana that located in the western region, and SDN 2 Kedungsana that located in the east. In addition, there are also two formal religious schools or Madrasas Diniyah, in the west is Madrasa Riyadul Mubtadi'in and in the east is Madrasa Miftahul Muta'alimin (table 3).

Meanwhile, the high school level is located outside Kedungsana Village. Those schools are in Plumbon District. Those are SMP Negeri 1 Plumbon, SMP Negeri 2

${ }^{1}$ Tajug is a mosque in the local language, as stated by Sunan Gunung Djati "Ingsun titip
Plumbon, MTs Pembangunan dan SMA Negeri 1 Plumbon, and several schools in Cirebon Regency and City.

Table 3 Educational Facilities in Kedungsana Village

\begin{tabular}{lcc}
\hline \multicolumn{1}{c}{$\begin{array}{c}\text { Educational } \\
\text { Facilities }\end{array}$} & $\begin{array}{c}\text { Numbe } \\
\mathrm{r}\end{array}$ & $\begin{array}{c}\text { Descriptio } \\
\mathrm{n}\end{array}$ \\
\hline $\begin{array}{l}\text { Madrasah } \\
\text { Diniyah/religiou } \\
\text { s school }\end{array}$ & 2 & \\
\hline $\begin{array}{l}\text { Elementary } \\
\text { School }\end{array}$ & 2 & $\begin{array}{c}\text { State } \\
\text { status }\end{array}$ \\
\hline $\begin{array}{l}\text { Junior High } \\
\text { School }\end{array}$ & None & \\
\hline $\begin{array}{l}\text { Senior High } \\
\text { School }\end{array}$ & None & \\
\hline
\end{tabular}

Source: Profile Data of Kedungsana Village.

Another education received children in Kedungsana Village was informal religious education conducted at Tajug, 1 which numbered 10 in various parts of Kedungsana village. Recitation in this tajug is usually done after ashar and maghrib. The study is almost the same as in madrasah, but different curriculum.

Among families of small farmers or farm workers who do not have land, they often neglect formal school education because of lack of income. They prioritize economic needs. Generally, the community of Kedungsana Village still considers that children are a source of energy for the family. It is shown by the number of elementary school students dominates from other school levels. For more details, shown in the following table 4 :

Table 4 Education Level of Kedungsana Villagers

\begin{tabular}{lc}
\multicolumn{1}{c}{ Education Level } & Number \\
\hline Elementary School & 562 \\
\hline Junior High School & 185 \\
\hline Senior High School & 282 \\
\hline
\end{tabular}

tajug lan fakir miskin”. It means I entrust the mandate to revive the mosque and help the poor. 


\begin{tabular}{lc}
\hline Diploma one to three & 25 \\
\hline Bachelor & 14 \\
\hline Boarding School & 7 \\
\hline
\end{tabular}

Source: Profile Data of Kedungsana Village.

\section{The Origin of Slametan in Kedungsana Village}

The background of various slametan including pregnancy slametan in Kedungsana Village is unclear how and when it started. According to the Lebe Syafi'i (40 years old):

It is not known for certain when it started. Since the day I was born, slametan had been carried out by residents of Kedungsana Village. It has been carried down from generation to generation, it is also possible that before the entry of Islam, it had been carried out. Then it was added Islamic religious elements by the saints and retained (Syafii, 2019).

$\mathrm{He}$ also explained that selametan were included in alms that was useful in preventing unwanted everything, related to death, fortune, and others. However, as he explained, that everything must return to God, the important thing is we try in a way that we believe whether by alms or slametan.

There are many types of slametan in Kedungsana: slametan to open the land before building houses, Slametan Munjuk Suwununan when start to build a house, slametan before a house is inhabited. For annual rituals, in Kedungsana village are also Slametan Hajat Bumi or Sedekah Bumi. In addition, there are also Islamic slametan such as Isra Mi'raj, Suroan, Muludan and Agustusan is separated slametan (Syafi'i, 2019).

The birth slametan is one of slametan rituals that still being carried out by the residents of Kedungsana Village. The birth slametan is a long series of rituals. Starting from Widungan Mapag Slametan when the obstetrical ages two months, Njaluk Ning Pengeran slametan after 3 months, Ngupati slametan in 4 months old, Memitu slametan after 7 months, and after reaching 9 months there was Nglolosi slametan ceremony. Do not stop here, after birth until weaned there are still many different types of slametan which will be discussed one by one below.

\section{Ritual Process of Slametan Memitu}

The Memitu tradition carried out by Kedungsana community is part of pregnancy slametan when the pregnancy reaches seven months. Another term commonly used is "Tingkeban" or "Seven monthly". It is called Memitu or seven months because the ritual is carried out when the gestational age reaches seven months. Seven is called pitu in Cirebon. While Tingkeban is derived from the word tingkeb, means has an even. When it reaches the age of seven months is considered to be even time, in which the baby is considered normal to be born.

This Memitu habit is as same as Javanese society's habit in general, namely to carry out customs or traditions that have been carried down by their ancestors. Shafi'i explained that the purpose of Memitu was to "dignify". So when the pregnancy ages seven months, the baby's limbs begin to be formed, such as ear, foot, hand and so on. It is also called Slametan Ngrujaki because the food of this ritual is fruit salad, as mentioned in Kidung Murtasiyah or the Song of Murtasiyah below:

Kidung Murtasiyah
Kekidungan cerita Dewi Murtasiyah
Lelakonan kasmaran si dangdang
gula
Kinanti megatruh sinom parijaka
Sesenggakan sendonan dalang
memaca

Kidung Murtasiyah ${ }^{2}$

Kekidungan cerita Dewi Murtasiyah

Lelakonan kasmaran si dangdang

gula

Sesenggakan sendonan dalang

memaca

${ }^{2}$ A song popularized by H. Abdul Ajib. Kidung Murtasiyah is one of the songs sing in Memitu ritual. 
Waktu bobot kebisan pitung wulanan

Siram kembang campur kidung rerujakan

Jambe riwe mecah blotong ning prapatan

Nandakaken si dadap lagi slametan

Reff:

Bluluk gading nggo anak-anakan

Ping pitu dangdan adus-adusan

Sampe nderegdeg digrujug esukesukan

Rena bunga kluarga pada curakan

Biasane tanggale pitu-pituan Guyub rukun sawengi pada melekan Ngalap berkah sawise amin-aminan Sesajian binagi pada bubaran

In English:

The absence of Dewi Murtasiyah's story

The story is about love and sugar

Kinanti megatruh parijaka

The puppeteer's voice chanted

When you are seven months pregnant

Flower bath mix and singing Jambe riwe breaks the barrel at the intersection

Indicates that there is a slametan

Ivory coconut for young children Seven times grooming when showering

Until shivering washed early in the morning

The happy family atmosphere at curse

Usually, the dates are all seven Gathering without sleeping all night Looking for blessings after amen Distributed food when dispersed

This song tells the process of Memitu. In a slametan ritual, the song is developed by the puppeteer reading (the poet who develops the ballad or who used to tell stories). This song activity is usually done in the evening while laying down to wait for the pot. It also tells about the process of spraying while changing cloth seven times. When bathed while carrying ivory coconut as a baby symbol (see figure 3), then the process of breaking blotong or barrel which is carried out in the intersection of the road. All preparation and implementation will be explained further below.

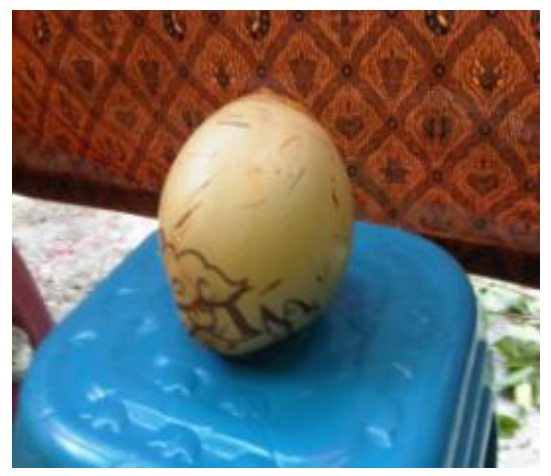

Figure 3 Bluluk Gading or young coconut that has been drawn by one of the puppet figures (usually Arjuna figure)

Source: Privat Documentation, 2018.

\section{a) Material for Slametan}

Although its implementation varies from one region to another in Cirebon, there are some similarities, including the materials for ceremonial purposes, namely:

1. Needles or but (7 pieces of cloth).

2. Decorated miniature house.

3. Pendil or pot (a kind of pottery used in the past to take water) containing water, various types of plants such as Banyan and sugar cane, as well as coins (Figure 4).

4. Seven types of flowers. Types of flowers can be anything, but generally in the form of Kingkong Flowers, Red Roses, White Roses, Cempaka Flowers, Kantil Flowers, Cananga Flowers, and Jasmine Flowers.

5. Offerings, which include: uduk rice, juwadah market, shredded salad, tamarind salad, banana salad, basil salad, various fruits and tubers, and cane 
wulung (black sugar cane). This salad consists of seven kinds of fruit. According to Syaiffuddin, food usually describes several parts of the body. For example, there are many cakes in form of ears, nose, hands and others made from flour.

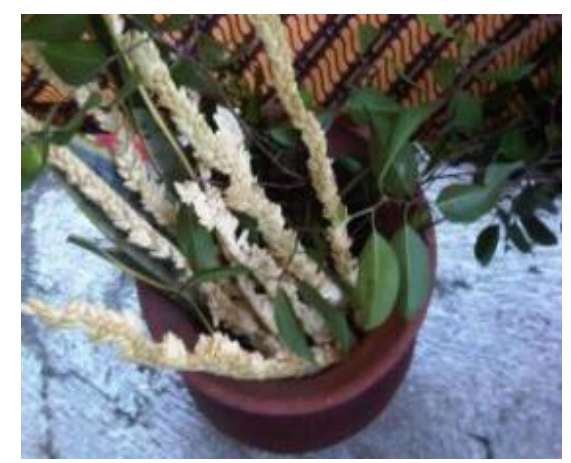

Figure 4 Pendil/Pot and Young Coconut for Memitu

Source: Privat Documentation, 2018

As Shafi'i explained, the water used for bathing comes from 7 different sources or 7 types of wells. Each block in Kedungsana Village still has a well whose water is usually taken to bathe in Memitu. Not only from well, but it also can be from Banyu Meneng (puddle) and Banyu Mili / Deres (flowing water). The well must be old and dug well. Among the wells are:

1. The well in Miftahul Muta'alimin Madrasah in Jamar Lor block.

2. The well in Tajwid's house in Sampurna block.

3. The wells in Mang Tori's house and Rosyid's house in Nyimas block.

4. The well in Kadmila's house in Jamar block.

5. The well in Sutini's house in the village block.

6. Puddle is taken from Soka River which is located in Karangtingtang block, Soka block in Danamulya village.

7. Banyu mili (flowing water) can be taken from water along Soka River.

The water is then mixed in a big container (large jug), nowadays it usually uses a barrel or paso. Then mixed with seven types of flowers, coins, and gold jewelry. The activity is repeated but in a different way. It uses pendil and gold jewelry is removed. Then, pendil is added by mixing manggar (coconut tree flowers) and banyan leaves. The next step, they made housings from bamboo decorated with oil paper flags, money flags, weringin leaves and wulung cane. In the house lay a cone with chicken roast. The equipment is better-taken care of by old people in order that no one steals money or jewelry in its housing and no animals enter the water.

Practically, the processions may not be carried out completely, it depends on the customs and regulations. For instance, when the slametan took place, Endang (32 years) just listened while sleeping. Mixed water was derived from the recitation, then used to take a shower shortly after the recitation was complete. He carried out a simple slametan, just inviting close neighbors, without a splash of rituals performed at home. It is caused by the lack of funds (Endang, Personal Communication, November 12, 2019).

\section{b) Timing and Procedure}

The residents did Memitu tradition in the afternoon or evening on Wednesday or Saturday and on odd dates before the 15th. The event begins with Barzanji reading in a house of people who have intentions (see figure 5). Then, followed by reading AlQur'an especially Surah Yasin, Luqman, Maryam, Yusuf, An-Nur, and Muhammad.

There is the reason why the people choose those Surah. The reason is to be able to take lessons and blessings from the contents of those Surah in Al-Qur'an. Actually, all Surah in Al-Qur'an have benefits, but they believe that these letters have priority especially with regard to the baby to be born. For example, Surah Yusuf and Maryam contain stories about both of them. It means that they hope their child will imitate Maryam if the baby is girl and will imitate the prophet Yusuf if the baby is boy. They conceive that their child has a handsome face and noble characters like the prophet Yusuf or beautiful face and noble 
characters like Maryam. Surah al-Waqiah means that they hope the baby's fortune is "overthrown" or easy to get off. Meanwhile, Surah Yasin means that they hope for the baby's salvation of the hereafter. The people of Kedungsana Village believe that these Surah affect the lives of their children.

There is placed a container filled with water among the people who are reciting Koran and Barzanji. After its reciting finish, this water will be mixed into a water container provided for bathing for both husband and wife in housing that has been provided outside the house, and the food is distributed. The husband and wife began to be bathed while reading prayer 3 times. People who bathe starting from parents, brothers and sisters, village elders, and followed by recitation worshipers.

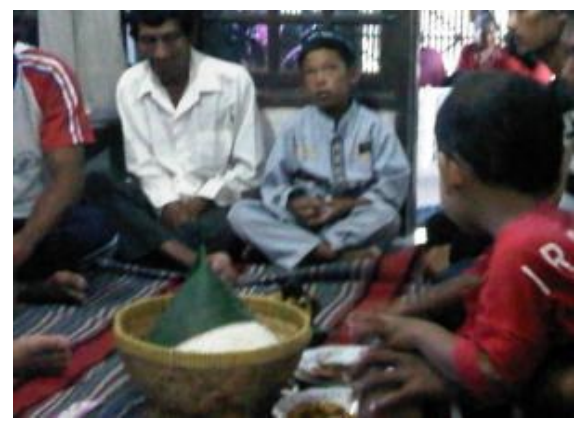

Figure 5 The atmosphere of recitation Source: Privat Documentation, 2018

When bathing, the wife only wore cloth and the husband only wore short drawstring. Every time someone bathing her, she changed cloth seven times. And at the turn of the seventh cloth, then the young coconut with puppet character was dropped through inside of the cloth used by the pregnant woman. seven pieces of cloth means that they hope their child's clothing will be provided every day in a week. Seven is based on the number of days in a week. Implied meaning of the cloth is all the need of their child, not just only cloth as explicitely mentioned before.

The husband then should catch the young coconut before it fell to the ground. According to Ustadz Subana, in the past, only wives were bathed, but in their development, the husband was also bathed. According to him, the most important is his brother. The only family is recommended. Because, It concerns genitalia (Subana, personal communication, November 14, 2019).

After bathing, the children around began to swarm the decorated housing. Without any instruction, they began to fight over housing decoration items such as balloons, flowers, paper decorations, and money. It is along with curak or saweran coins (figure 6). Curak or saweran is a procession of sprinkling coins toward a crowd people who are ready to catch it. Curak is a form of thanksgiving or in Islamic terms called Sadaqah. It means to excite joy and share with other communities.

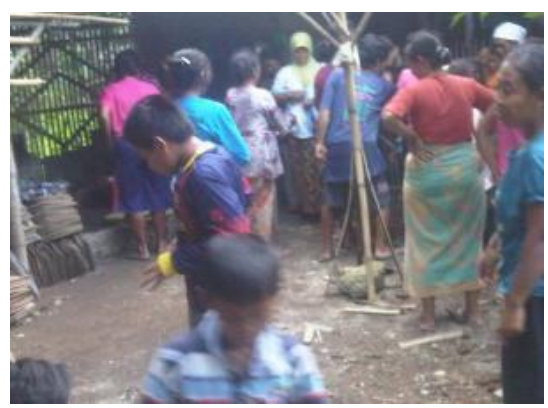

Figure 6 Curak

Source: Privat Documentation, 2018

The ceremony was closed by breaking blotong made by the husband. When it was broken in a crossroad, the children swarmed the sheared bank to find coins there. As stated by Shafi'I, the meaning jug rupture was the hope for an easy and smooth birth process like a jug rupture earlier. It is also a symbol for the community that there are pregnant women who have reached 7 months in order that they also prayed for them. The crossroad was chosen as a place to break the jugs because it is a place for passing and meeting people passing by. 


\section{c) Preparing for Darsono and Susi Family's Memitu Slametan}

The preparation started a day before the ritual. The male family prepares the housing (figure 7). The next day, the whole family prepared food. After dzuhur prayer, some of Darsono's brothers made housing from bamboo decorated with red and white oil paper and surrounded by clothes but shaped like the roof of a mosque. Then, banyan leaves, balloons, and money flags were added which children would be fought.

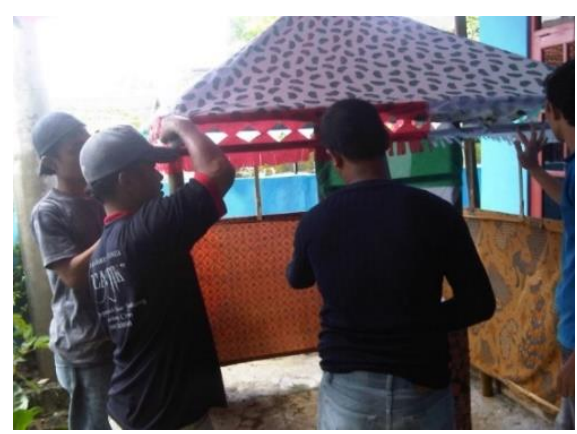

Figure 7 Preparing to Make Housing Source: Privat Documentation, 2014.

In the replica of the houses, there are doors and windows. Various objects that will be used for Memitu rituals such as buckets containing flower water, pendil containing flower water, banyan leaves, coconut flowers, coins, and a yellow coconut are laid in.

\section{d) Implementation of Memitu Slametan}

Early in the morning, Darsono invited close neighbors. The event then started at 7:30 by reading Maulid Barzanji. Then followed by siraman procession carried out by the family and then followed by recitation worshipers.
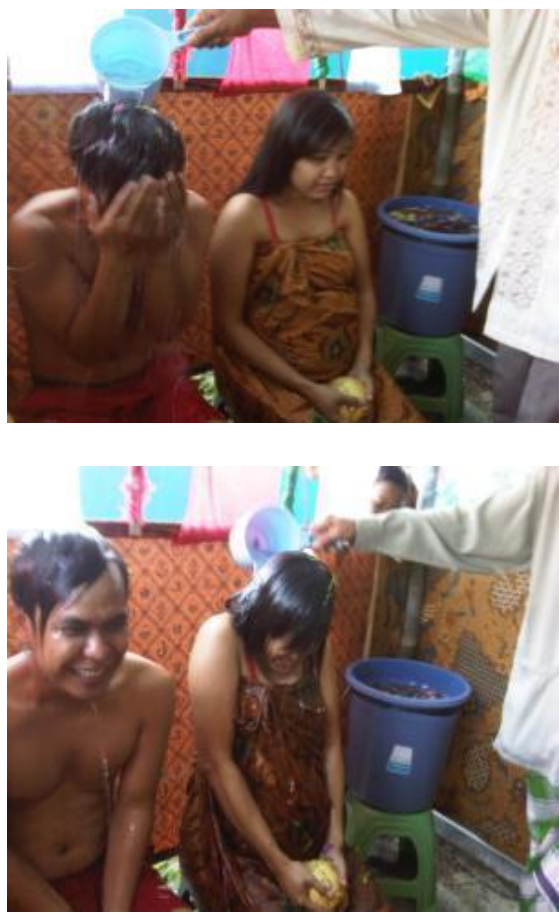

Figure 8 Family bathed Memitu Couple Source: Privat Documentation, 2014.

Every time someone splashed water, the yellow coconut must be dropped until the water run out (figure 8). Then, the husband took the pendil and runs to the crossroad or T-junction to break it (figure 9). The children and the surrounding community started to run and got ready at the location of breaking pendil to fight over the small change. The husband then took leftover items such as banyan leaves, coconut flowers and yellow coconuts to the river to be drained. When heading to the river, it is recommended to run and he was only allowed to bathe in the river. 


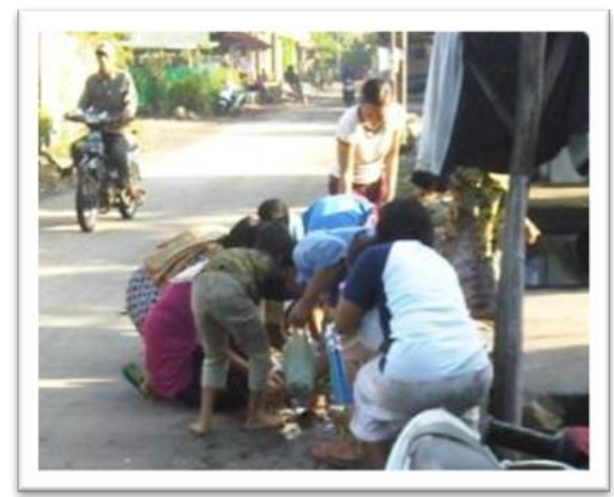

Figure 9 Children and community fight for pendil

Source: Privat Documentation, 2014.

\section{Changes in the Implementation of Ritual Memitu}

Nowadays, the community of Kedungsana Village has experienced modernization but the tradition of Memitu slametan is still carried out with various adjustments. Some of them still maintain their tradition, but not as perfect as before because of a lack of support either natural resources or human resources. It was stated by Muhyiddin (Personal Communication, November 14, 2019):

In various rituals, slametan births were always accompanied by singing. each singing needs various requirements. The requirement for slametan can be one pedicab. But since the arrival of Islamic boarding school students of Kedungsana Village, the residents begin to eliminate ritual activities because those are not part of Islam. But some residents still maintain the tradition, not erase all previous traditions. Even they get neighbors' ridiculous, such "actions that close the heaven gates", while imitating their statement.

Many community members do not carry out Memitu ritual because they realized that such behavior is almost unrelated to childbirth. Those are paganistic and one of the polytheistic activities. If there are sick children, they prefer to consult doctors to get medicine based on medical science, no longer need to use sacred cloth used to give birth. They believe that the smooth delivery process will be maximally achieved with good handling, not solely because of the sacred slametan rituals.

Kedungsana community faces two demands: the culture and the progress rationality. Some people recognize their cultural heritage by simply praying without rituals at the time of gestational age which is usually commemorated. The rest still actually maintain the cultural tradition of Memitu rituals even imperfectly because of the lack of supporting facilities either natural resources or human resources.

The change and adjustment happened at least three matters: birthing process, offerings, and ritual devices.

\section{a) Birthing process}

Childbirth in a traditional birth attendant through many processes was considered ineffective. It would be far more maximal through the right process such as routine checks on midwives. But it requires no small cost. Now, the government is participating through the Jampersal program to help pregnant women. The current role of the government through the Jampersal program is very helpful for the community. It was expressed by the village midwife, Siti Muharrum (Personal Communication, November 14, 2019)

Now pregnant do not need to worry about the cost of childbirth, the government has funded through the Jampersal program. Currently, delivery through birth shaman has been banned, but it does not mean they lose their jobs. They can still practice while accompanied by me. In addition to childbirth, they are still allowed to take care without being accompanied by me, such as sorting, bathing, and slametan ritual.

\section{b) Offerings}

According to Pengku (Personal Communication, November 11, 2019), there are certain things unapplied in Memitu 
in recent day. It was not because of mysticism or paganism but less efficient and effective. The problem of food or juwadah, for example, is almost certain that people today don't like its snacks. The taste buds of people changes. Thus, presenting this food in a ritual becomes a waste because there are just a few people eat it.

\section{c) Ritual devices}

The implementation of Memitu ritual is now almost extinct. The extinction of these cultural elements such as ritual devices. It is the impact of Islam acceptance as a new identity for them. Nevertheless, there are still some people who perform the ritual though not as perfect as before. The ritual has been simplified and replaced by reading the Qur'an together. Kidungan is changed to Marhabanan, then the community accepts because basically in Marhabanan it also contains songs.

Another change also is shown in the case of blarak. To make a blarak takes a long time. Its usage is placed by baskets or food wrappers from plastic. It is more efficient. As stated by Muhyiddin:

To carry out Memitu is difficult now. There is no one sing Kidungan in Kedungsana Village. It is also hard to find someone who can prepare blarak, coconut leaves which used to be a blessing container of distributed food to take home after slametan. Coconut trees are rare, even if it is available, who wants to make them. Whereas today, there is a container that is easier to get, namely plastic.

Those changes and adjustments occurred based on many factors: religion, thinking progress, advances in science, and technology, availability of natural resources and human resources, and economics.

As stated before that the most influential factor is religion. The community of Kedungsana Village realized that Memitu Slametan is not as Islamic teaching. Islamic boarding school students influenced them to change and adjust some rituals based on Islamic rules such as the reading of Marhabaan and declining offerings.

The second factor is the progress of thinking of members of the Kedungsana Village community. If religious factors change a lot in terms of birth slametan rituals, the progress of thinking greatly changes the essence and substance of culture. The point is through thinking progress, a critical assessment of culture has also begun to take shape, although it is still not evenly happened to all villagers.

Progress in community thinking is shown by the acceptance of a culture that is not part of their culture. In the slametan process, there is no reason for them not to accept new elements outside of their culture. In line with their level of education, almost all residents have experienced as a student at school, although it is still relatively low. It influenced the opening of their civilization. In addition to education, the information and communication channels that they have freely got to influence them. Almost every house has a television and communication device in the form of a telephone or mobile phone. The internet has also been known even though by a small part of the community of Kedungsana Village. It is proved by the existence of internet cafes, and facebook groups from Kedungsana villagers for their social networks such as Kedungsana Youth Collection which has 159 members (Kumpulan Pemuda Kedungsana, 2020), and Kedungsana Pesbukers group has 449 members (Pesbuker Kedungsana, 2020). Those made Kedungsana village community move forward little by little.

Cultural changes due to thinking progress factor is generally found in relatively young people. Some informants under 30 years old said that they did not carry out some slametan because they felt there was no direct benefit. One of them is offerings. During the research, there is only one person who still applies offerings. It was the procession of Muhammad Sohib Alifi. He could not give a strong reason for 
establishing offerings except hereditary tradition.

Both religion and thinking progress factors mentioned above cause loosening of customary law. It was stated by Ustadz Subana (Personal Communication, November 14, 2019):

Slametan Memitu with all its rituals is only customary law. And in the community, this customary law is flexible. There are no sanctions if anyone doesn't carry out it because it does not exist in Islam. It is possible to carry out it but keep Islamic worship is the most important.

The flexibility provides an opportunity for individuals to carry out or not the tradition based on their abilities. This "may not do" phenomenon illustrates the acceptance of other people's knowledge systems and the acceptance of other people's different actions.

The third is the advances in science and technology. It influences changes a lot, especially during the birthing process. The labor process has been replaced by the use of medical equipment and medicines. They assume that technology has removed elements of traditional culture in the birthing process. Technology in medicine is safer and even to determine sex can be known in advance with ultrasound technology (Ultra Sonography).

This is supported by a government policy that prohibits shaman to operate on their own and must also be accompanied by midwives. The costs of arranging childbirth are already funded by the government through the Jampersal program. As a result, people began to believe that what technology produced was the best.

The fourth factor is the availability of natural resources and human resources. Some residents still maintain various ritual traditions, but cannot carry out as before because of the limit of material commonly used in the ritual process. Such as difficulties in finding blarak due to material

${ }^{3}$ Memitu doer

${ }^{4}$ Doer of Memitu and nglolosi mixing limits and people who can make it. In Kidungan, singers of kidungan are almost extinct. Most of them have died.

The changing appetite of Kedungsana people has also influenced cultural changes in rituals. It is the fifth factor. Food used to be there in various rituals such as juwadah and salad is rarely found. Because when the food was served it was not eaten by the community members so it was replaced appropriately with people's taste now.

The final factor is the economic factor, as Petrakis \& Kostis (2013) that changes in the economic sector almost always cause important changes in the principles of kinship life. Several informants such as Endang ${ }^{3}$, Darsono ${ }^{4}$, and Sunemi ${ }^{5}$, said that they did not carry out a series of rituals due to lack of funds, in terms of their desire to carry out perfectly. This also seems to be supported by the openness of adat, which is also one of the factors causing cultural change.

In other words, how Memitu rituals are carried out by the people of Kedungsana Village have shown modernization. At least the element of modernization can be seen from an advanced way of thinking. In Soekanto's terms (1982: 360), scientific thinking institutionalized in a well-planned education and teaching system. Other modernization is shown by the use of medical devices in childbirth, the change of food according to the tastes of today's society, the use of mobile phones in inviting and reporting on the implementation of slametan rituals, and others. Maybe these changes are only part of the ritual elements of birth slametan, but what is clear is that they have changed, and the changes are visible.

Nevertheless, the six factors mentioned above do not necessarily change all aspects of culture in the implementation of Memitu rituals. In some places and members of Kedungsana village

\footnotetext{
${ }^{5}$ Puputan doer
} 
community, they still practice some aspects of culture including the ritual of birth slametan, even though it was not as thick as before. It is proof that in some ways the culture can change, but the original elements can still be found.

\section{Theological Dimensions of Memitu Slametan Rituals}

Instead of the change, the core processions must exist in the implementation of Memitu slametan of Kedungsana Village community as a characteristic and prerequisite for its implementation.

Kedungsana Village people also experience adjustments to the actual situation. To understand the theological dimensions in slametan Memitu in Kedungsana Village refers to the objective of holding slametan Memitu. The objectives consist of preserved values which in line with the current community context. The objectives of the slametan Memitu of the Kedungsana Village community are related to three things: a) expressing gratitude to God Almighty; b) requesting special safety and fluency during the process of pregnancy to birth; c) building brotherhood and harmony among people.

\section{Belief Dimension of the Invisible Substance}

Every construct of theological ideas always has the main dimension to belief in the transcendent substance, because theology principal is science or ideas related to God. In the Dictionary of Philosophy and Religion, William L. Reese explains that theology is a discourse or thought about God (discourse or reason concerning God) (Reese, 980). Theology can also be interpreted as a concept of thinking and acting that is associated with the "Unseen or Invisible" which creates and regulates humanity and nature (Nugroho, 2018). Therefore, the concept of theology has always been the basis in a particular religion or belief. It is a variant of thought or discourse about God that makes a variant of religion, belief, and even sects in a religion or belief. When a theological thought is structured in such a way in the context of modern society, the idea of belief in God or the Creator and Ruler's Substance remains the center of theological thought.

The Memitu slametan ritual is a Javanese tradition that has carried on for generations as a form of expression of gratitude to God Almighty and the hope of safety, and special fluency during the process of pregnancy to birth. In its original form, gratitude for the ritual is addressed to the Invisible Substance which is considered to be the ancestor, especially the founders of the Village, their spirits are considered to be alive and have the power to protect the entire village community. When Islam entered, the introduced Magic Substance to the people in Cirebon was God as the Creator, Ruler, and Determinant of the smoothness in human life, including fluency in the process of pregnancy and birth. In other forms.

Even orientation of the "supernatural substance" has changed adapted to Islamic beliefs, there is still remnants of old beliefs such as the presence of Suguhan or offerings. When the memorial slametan ritual takes place, there are offerings placed at home, or in certain places that are believed to have a watchman like on a bridge located near the house. The offerings contain apem, tofu, rumba, limpung, fried sambal, rice, salted fish, and water (figure 10).

The same food is also provided for slametan Memitu worshipers. As explained by the Shafi', the offerings on the bridge is an old belief. It is intended to prevent bad things. It is placed almost in every places believed to have a waiting person that sometimes will affect the celebration such as a celebration food is not ripe. It is not just a myth because it has happened.

For the Muslim community in Kedungsana Village today, gratitude and prayers for requests for salvation are still addressed to God, not to others. Even though they also have a variety of cultural 
orientations, the intended God symbol is God. It is as stated by Ustad Syafii, for him, the Memitu slametan ritual is part of the culture that developed in the Kedungsana Village community.

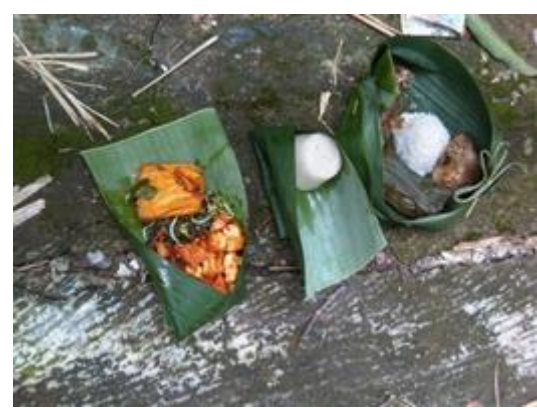

Figure 10 Offerings placed in the bridge Source: Privat Documentation, 2018

The ceremony is believed not to deviate from Islamic teachings. He stated, "The ceremony is an acculturation of culture and religion. What unites is only the prayer ritual together. Its activity does not against Islam because it is filled with verses of the Qur'an and reading of Barzanji's book. The tradition of reading the Qur'an and Barzanji is very important to do in Memitu tradition because according to the Kedungsana community when the fetus in the womb enters the age of seven months, the fetus is already perfect, and has a complete body structure. It is clean and free from sin. Such conditions are perfect conditions to be a reference for good Muslims in their spiritual endeavors.

\section{Values Dimensions of Harmony}

Islam has a theological basis so that its people participate in maintaining harmony and friendship. There are several Qur'anic texts and traditions that explain the importance of maintaining harmony and friendship such as QS. Muhammad [47]: 22-23, Q.S. An-Nisa [4]: 1. There are also several traditions cited in Hadits of Baihaqi, HR Ahmad, Tirmidzi, Abu Daw HR Ahmad, Tirmidhi, Abu Dawud, and also Imam Bukhari and Muslim. Thus, harmony and friendship become important teaching in every religious treatise, not least on the Islamic theological system (Ghazali, 2013).

In the context of Memitu slametan ritual, Ustad Syafii has said that the essence of it is not only for gratitude and the smooth cultivation of the birth process but also as a form of brotherhood among the community. This is reflected in the procedures for carrying out the slametan Memitu ceremony. The residents gather and work together, help each other among communities, preserve cooperation value, and eliminate individualism. Because human beings are essentially social beings who cannot live alone, they will depend on each other and need help from others. The whole steps of ritual need help from others such as building housing, recitals, making food or salad, until prospective parents. The harmony among neighbors will be created. Thus, this tradition can build the values of togetherness or the values of cooperation and maintain the integrity of the community and relatives.

\section{CONCLUSION}

In general, there are three objectives in Memitu ritual in the Kedungsana Village community today, namely expressing gratitude to God Almighty, asking for special safety, and smoothness during the process of pregnancy to birth and building brotherhood and among the community.

Based on the goals and procedures of slametan Memitu rituals implementation in Kedungsana Village, the theological dimensions of the ritual can be identified as belief in the Invisible Substance and values for living in harmony among the residents of Kedungsana Village. The theological dimensions in the earth alms ritual have been developed in such a way as to be in line with social reality development. It shows that religion or belief is not merely related to normative and doctrinal issues but also dialectics. It makes accommodations or collaboration with the so that theology has a practical value felt directly by the community. 


\section{REFERENCES}

Abdullah, W. (2018). Local Knowledge and Wisdom in the Javanese Salvation of Women Pregnancy 'Mitoni': An Etholinguistic Perspective. Fourth Prasasti International Seminar on Linguistics (Prasasti 2018).

Adriana, I. (2012). Neloni, Mitoni Atau Tingkeban: Perpaduan antara Tradisi Jawa dan Ritualitas Masyarakat Muslim. Karsa: Journal of Social and Islamic Culture, 19(2), 238-247.

Afif, H. (Ed.). (2009). Harmonisasi Agama dan Budaya di Indonesia. Balai Penelitian dan Pengembangan.

Amirudin, Y. (2019). Nilai-Nilai Pendidikan Islam dalam Tradisi Mitoni di Malang. Vicratina: Jurnal Pendidikan Islam, 3(1), 137-145.

Baihaqi, I. (2017). Karakteristik Tradisi Mitoni Di Jawa Tengah Sebagai Sebuah Sastra Lisan. Arkhais: Jurnal Ilmu Bahasa Dan Sastra Indonesia, 8(2), 136-156.

Boanergis, Y., Engel, J. D., \& Samiyono, D. (2019). Tradisi Mitoni Sebagai Perekat Sosial Budaya Masyarakat Jawa. Jurnal Ilmu Budaya, 16(1), 49-62.

Busro, B., \& Qodim, H. (2018). Perubahan Budaya dalam Ritual Slametan Kelahiran di Cirebon, Indonesia. Jurnal Studi Agama Dan Masyarakat, 14(2), 127-145. https://doi.org/10.23971/jsam.v14i2.699

Endang. (2019, November 12). Personal Communication.

Ernawati, D. (2017). Ritual Pitonan Adat Jawa Menurut Tinjauan Hukum Islam (Studi Kasus di Desa Laloumili Kec. Lalembuu Kab. Konawe Selatan). IAIN Kendari.

Geertz, C. (1981). Abangan, Santri, Priyayi Dalam Masyarakat Jawa (A. Mahasin (Trans.)). Pustaka Jaya.

Ghazali, A. M. (2013). Teologi Kerukunan Beragama dalam Islam (Studi Kasus Kerukunan Beragama di Indonesia). Analisis: Jurnal Studi Keislaman, 13(2), 271-292.

Isa, R. M., Man, S., Rahman, N. N. A., \& Pauzi, N. (2019). Pengamalan Wanita Hamil dalam Masyarakat Melayu dari Perspektif
Islam. Jurnal Fiqh, 16(1), 191-224.

Juwintan, J. (2017). Analisis Semiotik pada Adat Nujuh Bulan di Cirebon. Syntax Literate; Jurnal Ilmiah Indonesia, 2(6), 45-54.

Kumalasari, L. D. (2017). Changes of Mitoni Tradition In Ngogri Village, Megaluh Subdistrict, Jombang. In Research Report.

Kumpulan Pemuda Kedungsana. (2020, June 12) Member of Kumpulan Pemuda Kedungsana Privat Group. https://www.facebook.com/groups/33086 4360333753/?fref $=$ ts\% 20 accessed

[Facebook update] Retrieved from https://www.facebook.com/groups/33086 4360333753/members

M Ikhfan, T. (2019). Tradisi Mitoni dalam Perspektif Hukum Islam(Studi Kasus Di Desa Laren Kecamatan Bumiayu Kabupaten Brebes). IAIN Purwokerto.

Muharrum, S. (2019, November 14). Personal interview.

Muhyiddin. (2019, November 14). Personal interview.

Newland, L. (2001). Syncretism and the Politics of the Tingkeban in West Java. The Australian Journal of Anthropology, 12(3), 312-326.

Nugraha, A. (2015). Aktivitas Komunikasi Dalam Upacara Adat Nujuh Bulanan Di Kota Bandung (Studi Etnografi Komunikasi Mengenai Aktivitas Komunikasi Dalam Upacara Adat Nujuh Bulanan Di Kota Bandung). Universitas Komputer Indonesia.

Nugroho, H. (2018). Dimensi teologi dalam ritual sedekah bumi masyarakat Made. Islamika Inside: Jurnal Keislaman Dan Humaniora, 4(1), 24-49.

Pengku. (2019, November 11). Personal interview.

Perbuker Kedungsana. (2020, June 12) Member of Kumpulan Pemuda Kedungsana Privat Group.

https://www.facebook.com/groups/36783 5336049/ [Facebook update] Retrieved from

https://www.facebook.com/groups/36783 5336049/members 
Petrakis, P., \& Kostis, P. (2013). Economic growth and cultural change. The Journal of Socio-Economics, 47, 147-157.

Reese, W. L. (1980). Dictionary of Philosophy and Religion. Humanities Press.

Rifa'i, M. (2017). Etnografi Komunikasi Ritual Tingkeban Neloni dan Mitoni Studi Etnografi Komunikasi Bagi Etnis Jawa di Desa Sumbersuko( )Kecamatan Gempol kabupaten Pasuruan. Ettisal Journal of Communication, 2(1), 27-40. https://doi.org/10.21111/ettisal.v2i1.1411

Rois, A. (2015). Tradisi Mitoni dan Implikasinya Terhadap Pendidikan Anak Pranatal dalam Perspektif Islam. UNISNU Jepara.

Silalahi, U. (2010). Metode Penelitian Sosial. Refika Aditama.

Soekanto, S. (1982). Sosiologi Suatu Pengantar. Penerbit Rajawali.

Subana. (2019, November 14). Personal interview.

Suhartiningsih, S. (2014). Perubahan Ritual Peralihan Tahap Kelahiran Budaya Jawa Pada Masyarakat Desa Purwosari Kecamatan Tamban Kabupaten Barito Kuala. Jurnal Socius, 3(2). https://doi.org/10.20527/jurnalsocius.v3i 2.3261

Syafii. (2019). Personal interview.

Ulya, I. (2018). Nilai Pendidikan dalam Tradisi Mitoni: Studi Tradisi Perempuan Jawa Santri Mendidik Anak dalam Kandungan di Pati, Jawa Tengah. Edukasia Islamika, 116-130.

van Gennep, A. (2004). The Rites of Passage. Routledge.

Wariin, I. (2014). Nilai-nilai Kearifan Lokal (Local Wisdom) Tradisi Memitu pada Masyarakat Cirebon Studi Masyarakat Desa Setupatok Kecamatan Mundu. Edunomic Jurnal Pendidikan Ekonomi, 2(1). 